\title{
THE FINANCIAL RELATIONSHIPS BETWEEN FARMERS, CREDIT INSTITUTIONS AND PUBLIC AUTHORITIES - SHORT REVIEW
}

\author{
Gabriel Popescu', Alina Zaharia ${ }^{2}$ Daniela Mihai ${ }^{3}$, Roxana Chiocaru ${ }^{4}$
}

\begin{abstract}
Summary
Agriculture is the sector that satisfies the demand for food of the population of a state, thus providing key solutions for combating poverty and / or hunger. The need for funding in agriculture is increasingly debated at international level, especially as discrepancies arise in relations between the main actors involved, namely: farmers, credit institutions and national and European public authorities with the aim of the European funds management. The relational problems, and not only, of the three actors mentioned above are manifested in various forms. These are discussed in this paper. Under these conditions, it is proposed to strengthen the relationship between the three actors, first by assessing the existing problems and, secondly, by solving them.
\end{abstract}

Key words: agriculture, credit, European funds, farm, financing.

JEL: $Q 14$

\section{Introduction}

Agriculture is the factor that meets the demand for food for the population of a state, thus providing key solutions to combat poverty and / or hunger. In this way, the funding role of this economic sector should benefit from a hierarchical prioritization in terms of the allocation of funds, as it mediates commodity transactions that simultaneously meet characteristics such as nutritional safety and sustainability (Reti and Bak, 2016).

1 Gabriel Popescu, Ph.D., Professor, Bucharest University of Economic Studies, Department of Agrifood and Environmental Economics, Mihail Moxa Street no. 5-7, $1^{\text {st }}$ sector, 010961, Bucharest, Romania, Phone: +4.021.319.19.00/int 138, E-mail: popescug2004@yahoo.co.uk

2 Alina Zaharia, Ph.D., Teaching Associate, Bucharest University of Economic Studies, Department of Agrifood and Environmental Economics, Mihail Moxa Street no. 5-7, $1^{\text {st }}$ sector, 010961, Bucharest, Romania, E-mail: alina.zaharia00@gmail.com

3 Daniela Mihai, Ph.D. Student, Bucharest University of Economic Studies, the Economics II Doctoral School, Tache Ionescu street, no.11, $1^{\text {st }}$ sector,010352, Bucharest, Romania, E-mail: daniela.mihai@aldis1990.ro

4 Roxana Chiocaru, Master student, Bucharest University of Economic Studies, Faculty of Agrifood and Environmental Economics, Mihail Moxa Street no. 5-7, $1^{\text {st }}$ sector, 010961, Bucharest, Romania, E-mail: chiocaruroxana@gmail.com

EP 2018 (65) 1 (427-436) 
As can be seen from the studies carried out so far (Miteva, 2005 and Bojnec, 2012), different parameters may give a different form to land capital markets and agricultural financing systems, the auspices to which these indicators are subjected are decisive for the final stage in which the population has access to planned economic structures at the level of a political body.

The multifunctionality of the roles that agriculture develops within a country's borders can be borne out by various and different economic mechanisms, as folding on the structure of farms and, in particular, their size, they are demanding agricultural policies geared to the agrarian needs of a country, many times, even if they are part of the European Union, they have characteristic features very different from the country that is part of the same alliance (Hungary and Slovenia, Slovenia being a small country, the most common agricultural organizations we find in the form are the family farms, and in Hungary, a country with larger land plots, the highest frequency of business is represented by large agricultural companies), and this also requires adapted agricultural policies and government support. (Bojnec et al., 2014)

In this context, the present research aims to revise the relations between farmers and credit institutions, respectively the relations between farmers and the public authorities with their object of managing the European funds. The subject discussed from the perspective of the need to finance agriculture, refers to both international situations and specific situations, such as Romania.

\section{The relationship between farmers and credit institutions}

In order to sustain the competitiveness of Romanian agriculture in the first year since Romania obtained its status as a member country of the Union, in 2007, it was applied to agricultural policy measures involving a single payment scheme on the land used up to to various forms of financial support in the intervention sector in penetrating and maintaining the agri-food business market. (Alexandri and Luca, 2012)

The combination of non-reimbursable European funds and of the crediting of agriculture by different institutions in this field leads to the development of Romanian rural in the parameters of market mechanisms. As the absorption of these amounts is deficient due to the co-financing component to be supported by the project beneficiary, Romania cannot cope with the rigid EU deadlines, some of them reorienting to banks to purchase agricultural credit services from their portfolio.

There are some opinions (Stratan, 2014) who argue that the liberal-type policy applied in agriculture should be coupled with the interventionist type because measures such as price subsidies and production factors as well as preferential lending may be small changes to give a better version of agriculture as a whole. A solution to not regress the Romanian agriculture could be represented by the guarantee of the real price of the domestic market, but the limitation of this is driven by the conditioning imposed by the forms of production storage, or even more frequently, by the lending programs. 
In literature (Dodson, 2014) believe that small banks are based on establishing a credit relationship built with a subjective assessment of creditworthiness. This advantage can be considered from a hierarchical perspective because the organizational structure and bureaucracy are lower, and in this way the distraction between the loan officer and the company management is lower, so the time of eligibility and credit granting analysis is also lower. (Berger and Udell, 2002)

Smaller agri-food businesses can be more powerful candidates in the agricultural credit market because it is easier for them to maintain more detailed financial records compared to intermediate or large and very large ones. (DeYoung et al., 2004). Berger et al. (2001) found that banks are more reluctant to lend information to opticians, while small lending institutions have proved to be better at processing and assessing credit applications for small firms.

In order to find out and rank risk ratings, large banks are gaining ground because they are likely to have access to larger databases such as small ones, with homogeneous groups of local investors, which allow the lender to assess the risk of the lender transaction. In calculating borrowing performance, banks have lately used in an intensive manner technologies involving the use of asset-based lending and adapted to the financial situation as well as the credit score instrument. (Berger and Udell, 1998)

The risks arising from the relationship between farmer and credit institutions have attached unexpected variations in the cost and availability of credits. Their sources come from the coercive forces on the market and the creditors' responses to the risks on the agricultural market and their creditworthiness. Empirical evidence from studies on risk from the creditor shows that the loan made by farmers is directly correlated with farm incomes, so it can be concluded from this relationship that there is a stronger correlation in the case of loans supporting the development of capital than those made for supporting operational systems. Increased credit risk is more prominent in the market by diversifying the credit portfolio made available by lending institutions. (Barry and Ellinger, 1989)

Agriculture and the businesses that this business sector involves are full of challenging challenges for operators of any kind, age or size. This business sphere calls for ample investment because the capital needed to put it into operation is not at all negligible in value. There is a need for investment in land, buildings, equipment, seeds, or if the zoo is concerned, then a significant number of animals and feeds are needed. Oscillating, unreliable commodity prices, fuel, interest rates, and meteorologically negative events put the entrepreneurs on the agri-food market in a hurry, making both investors and creditors alike think their involvement on this market. These challenges are especially felt by young people, novices or small producers. That is why they need not only a credit from the lending institutions, but also a handful of help from them, which is necessary for the establishment of potential clients.

Currently, agri-food lending markets need to be flexible in their approach, as demand in the market is divided, with predominantly small customers. Access to credit is considered in the literature (Besley, 1995 and Zeller and Meyer, 2002) as a key requirement of economic growth and then of raising the standard of living in more or less developed rural areas. 
Poor households in transition or developing countries often have the main source of income for agriculture, and at the macroeconomic level this is the branch of the economy that contributes most to the GDP of the country. In these cases, it is necessary to consider the clients and to rationalize the amounts that banks generally make available to consumers. (Petrick, 2004)

Taking into account a macroeconomic approach it is necessary to maintain prosperous relations between small and large farmers and credit institutions in order to develop Romanian agriculture, because through its evolution the Romanian agri-food businesses will not only produce raw materials but will process what they obtain within their enterprise, and this will create gross added value, a taxable element by state forces.

The main conditioning of this business relationship between the two entities mentioned above is through the interest that customers have to pay to the lender. Its variability is conditional on the activity flow of small farms. In Romania, at present, agricultural loans are granted for a maximum of 20 years. In 2017, the Romanian bank CEC Bank announced a variable interest rate on agricultural loans of $4.31 \%$ per year.

Granting loans to subsistence farms or micro-farms is a delicate issue, and lending institutions are reluctant to do so because these small businesses can easily remain without liquidity. Due to the fact that they do not engage in large capital and sufficient labor, these investments can easily fail the lender to recover the borrowed amount and the price for it, the interest.

On a large scale, in a theoretical scenario, if a lending institution would predominantly support small businesses, beginners and subsistence farms, it would have a chance to go bankrupt in a very short time, because operators quoted earlier may enter the crisis facility liquidity.

Their liquidity crisis will also arise over the debtor institution under the domino effect, because when it operates with money deposits it runs through lending, with the institution's profit being the difference between lending interest and deposits. If loans and lending rates are not honored by clients, they will not have sufficient financial resources to honor the time deposits, sorting out the financial institution to failure.

The precaution that the banking institutions have in the agricultural sector has its origin and the many risks that the work in this field has to do. In particular, the borrower cannot assume the risk of the incidence of meteorological events in the form of calamities that would cause the farmer to temporarily stop the farmer's income streams, so he would not allow him to pay in due time his credit and interest. Even though the profile institutions come with a great diversity in the lending area in their portfolios, the rate of absorption of these financial services is predominantly low because the eligibility of potential clients is below the allowances considered admissible for the borrower. (Winter-Nelson and Temu, 2005)

Reasons behind government programs to make farmers available to direct lending can lead to information asymmetry problems in capital markets, and the benefits that are made available to customers can lead to a national financial relaxation that is not always desirable. 
Whether government intervention on credit markets can achieve legitimate objectives, it depends on the mechanism chosen for the implementation of dedicated credit. In some cases, the marketing constraints that agri-food entrepreneurs may have may hinder reimbursement terms which farmers can accept for good credit management and in this situation government coercion is insufficient. In other cases these problematic situations are avoided by establishing credible market mechanisms to ensure the allocation and reimbursement of credits. (Calomiris and Himmelberg, 1993)

The relationship between the farmer and the lending institutions can take tense or stable forms; in Romania the preponderance is unfortunately the first option, often due to the instability of the Romanian or the political taxation, which stops programs destined to allocate funds for development sustainability of Romanian agriculture.

In these circumstances, it is proposed to strengthen the relationship between the two actors, first by evaluating the existing problems and then by solving them.

\section{The relationship between farmers and the public authorities with the aim of evaluating, managing and monitoring the European funds}

One of the most prominent problems in line with EU funds for agriculture is their low absorption rate, with Romanian farmers being able to access only a small percentage of the sums allotted through programs aimed at supporting them, and at the macroeconomic and general level, the development of rural life as a whole.

The primary cause of the low absorption rate of the Structural Funds is correlated with the delays in the development of the programs at national level and because of the decisions taken from Brussels, reported to the European Union budget. Another issue of concern is the lack of transparency in the government, especially in the administrative management of programs, in which case the responsible ones avoid accepting that there are challenges and vulnerabilities in ongoing projects, showing only positive aspects of European projects. Avoided solving and looking for solutions to the blockage of European funds, creates economic harm first and foremost to the farmer, and secondly to the national economy.

Another problematic interest point in the rate of absorption may be the banking system, setting conditions that are difficult to meet for the average farmer, and in most cases they cannot come up with a sufficient co-financing budget.

We also encounter bureaucracy, in some cases it is present in excess, and this can degenerate in cases of corruption. Romania's recent years had to deal with political conflicts which then turned into real crises, the economic barometer also recording irregularities in allocating according to the plan communicated to the population. Thus, due to the tense relations between the executive branch and the potential beneficiaries, but also within the executive branch, one can easily see how the deadlines of the agro-alimentary financing programs reach maturity, when they actually do not even have in the Romanian space beginning.

Diversification of income sources is a strategy that aims to reduce the risk to the farmer of losing his purchasing power in the input market, because the absence of this market 
in the role of buyer would make him obvious, non-existence in the output market. It can therefore be seen in this context the importance of maintaining a good relationship between the farmer and the authorities in charge of the management and good course of money from European programs as a food security perspective.

The availability of money from European funds increases both incomes and consumption as a result of increased productivity thanks to investments and the degree of modernization of agrifood businesses (Schroeder, 1996, pp. 345) at national level. Rural financial institutions dealing with the allocation of financial resources for agriculture must have a flexible and understandable approach for small farms or young farmers by providing them with education services in terms of support. In this way long-term food insecurity can be avoided by providing non-reimbursable farmers to support the productive process that is politically threatened by rising fuel or commodity prices or weather threatened by the weather in climate change.

For the current period, 2014-2020, through the program for rural development, NRDP, it is worth about 9.3 billion euros. (Rus Ma et al., 2015). The achievement of the European average relative to the western rural environment, the standard of living, the level of modernization and the overall socio-economic development of those areas as a whole, are under the sign of the above-mentioned amount of money, through its good management, diminishing the existing disparities the current moment.

At the level of European funds monitoring, there can be a lack of a serious audit tool that will accurately check the investment of the financial resources allocated after the winning of the project. And so, it can also be called the small shortcomings of the risk analysis seen from the point of view of the need to refine financial statements. Also, the provisions, which imply the taken measures in the case of the insolvency of a company that is running a program which has allocated European funds, most probably nonreimbursable, are also perfect.

From the same perspective, authorities managing Structural Fund allocations have no protection against the political risk of Romanian political instability. Also, no device performs and does not require the use of time-frames to build a dedicated profile with which to establish a potential co-financing or reimbursement capability, as the case may be.

One of the issues raised in the relationship between the farmer and the public authorities is the internalization of the capacity for evaluation and monitoring of the funds, respectively the client, which currently suffers from a large deficit. As this process is cumbersome and unfruitful, it often calls for external assistance, and this process is expensive and could be reduced by good human resource management.

Another negative effect is that, at present, the outsourcing mentioned above does not go to native companies but foreign ones, this fact not holding the positive evolution of the Romanian economy. The appreciation that there will be a rebate on the quality of the service is unfounded, the services offered by a Romanian or foreign company being with the same nature but differentiated costs. (Kehew, 2000) 
A solution that could address these problems would be, firstly, the outsourced services provided by enterprises with Romanian capital, and then the staff of the public authorities should be trained according to the needs of the workplace.

A not negligible threat of absorption of European funds is a lack of rigorous procedures and methodologies for public sector authorities operating with this type of finance.

At present, there is great pressure in Romania to quantify the progress of structural funds absorption and to identify adjustments to the shortcomings found during the running of the programs, in this manner desiring the design of public policies in the country's supposed ideology. (May, 2006)

Over the past two decades, the European Commission has played a decisive role in shaping a culture of project outcome evaluation or project implementation, introducing elements of cost-benefit analysis as a tool for monitoring the gradual need for funding. (Mairate and Angelini, 2006) In Romania there are several institutes dealing with this evaluation research, among which the Romanian Academy, the European Institute in Romania or the Center for European Policies in Romania. (Cace et al., 2011)

The Economic Growth Stimulation Policy addressed by U.E. is based on endogenous growth patterns such as those suggested by Robert Lucas in 1998, or by Grossman and Helpman in 1991. The main instruments the Union uses to achieve economic growth consist of subsidies for private or public operators. This management of structural funds has often had the questionable ethics. (Hapenciuc et al., 2013)

According to specialized studies using modeling of economic processes as a forecasting tool (Zaman and Ahmad, 2008), the absorption of European funds could have a significant impact in Romania, helping to smooth the process of convergence and also to reduce disparities and disparities. According to the estimates, for the period 2004-2020, Romania could have an annual economic growth that would vary between $0.1 \%$ and $0.2 \%$. However, in reality, the absorption of the financial resources made available has been greatly diminished by the lack of experience of potential applicants and the lack of trust due to insufficient and faulty promotion of this service at national level.

With the previous crisis, which started in 2008, unnecessary needs and problems emerged that still require a reconfiguration of the manners of allocating, managing and absorbing structural funds. (Neculita, 2013)

At present, in Romania, the relationship between the farmer and the public institutions which have as their object the management of European funds is superficial and cumbersome due to the multitude of eligibility criteria that a farmer has to present and on the other hand the effective transfer of money resources to the project winner, long delayed due to various factors of influence. The instability of this relationship further blocks the absorption of structural funds into Romanian agriculture, asking both sides about the ethics of the business partner and the Romanian economy remains suffering due to political, social and educational limitations. 
Under these circumstances, it is proposed to strengthen the relationship between the three actors, first by evaluating the existing problems and then by solving them. The evaluation can be carried out at local, regional or national level depending on the degree of diversity of each country, by means of an inquiry which can highlight the prospects of each party investigated and the points of inconsistency to be resolved in order to facilitate the financing of agriculture.

\section{Conclusion}

The approach of the economic agents involved in agricultural activities must not affect the national limitations but rather address a wide macroeconomic angle that follows the global economic development network in terms of sustainability. The development of each field of activity is produced by constant, qualitative and quantitative monitoring of its structures, substructures and implicit mechanisms. So, the importance of an efficient financing apparatus is justified by the operation of an investment regime able to sustain the macroeconomic dynamics of the dynamics of a given economy. This analytical body requires a constant adaptation to the structure of input-output flows in order to connect to a simple and not simplistic system based on the basic economic principle of the minimum and maximum. Therefore, this observation angle aims to increase the entrepreneur's ability to control the management of the resources involved and the quantity and quality of the finished product he will have.

The agriculture financing process has not only a financial, but monetary, but it goes on, describing a science that exceeds monetary limitations, being tangent to the social dimension.

The importance of financing agriculture is becoming more and more aware of both farmers, credit institutions and national and European public authorities, but these actors are hardly able to eliminate the distortions that have arisen in today's agriculture. The relational problems, and not only, of the three actors mentioned above are manifested in various forms that have been discussed in this paper.

In Romania, the relationship between the farmer and the lending institutions is tense by the instability of Romanian or political taxation. Also, the relationship between the farmer and the public institutions which have as their object the management of European funds, which is often difficult, creates bottlenecks in the absorption of structural funds for Romanian agriculture.

Finally, the relational problems between farmers, credit institutions and national and European public authorities, which have as aim the management of European funds, generate the diminishing of the efficiency of programs meant to allocate money resources for the sustainable development of the Romanian agriculture. Therefore, it becomes necessary to improve the relationship between these actors. 


\section{Literature}

1. Alexandri, C., \& Luca, L. (2012). The role of small farms in Romania and their future in the face of challenges of the CAP post 2013. Problemy Drobnych Gospodarstw Rolnych, (1), 13-30.

2. Barry, P. J., \& Ellinger, P. N. (1989). Credit scoring, loan pricing, and farm business performance. Western Journal of Agricultural Economics, 45-55.

3. Berger, A. N., \& Udell, G. F. (1998). The economics of small business finance: The roles of private equity and debt markets in the financial growth cycle. Journal of Banking \& Finance, 22(6), 613-673.

4. Berger, A. N., \& Udell, G. F. (2002). Small business credit availability and relationship lending: The importance of bank organizational structure. The Economic Journal, 112(477).

5. Berger,A. N., De Young, R., \& Udell, G. F. (2001). Efficiency barriers to the consolidation of the European financial services industry. European Financial Management, 7(1), 117130.

6. Besley, T. (1995). Nonmarket institutions for credit and risk sharing in low-income countries. The Journal of Economic Perspectives, 9(3), 115-127.

7. Bojnec, Š. (2012). Agricultural and rural capital markets in Turkey, Croatia and the FYR of Macedonia. Agricultural Economics-Czech, 58(11), 533-541.

8. Bojnec, Š., Kvasha, S., \& Oliynyk, O. (2014). Agricultural financial systems in Slovenia and Ukraine. Bulgarian Journal of Agricultural Science, 20(2), 458-468.

9. Calomiris, C. W., \& Himmelberg, C. P. (1993). Directed credit programs for agriculture and industry: arguments from theory and fact. The World Bank Economic Review, 7(suppl_1), 113-138.

10. Dodson, C. (2014). Bank size, lending paradigms, and usage of Farm Service Agency's guaranteed loan programs. Agricultural Finance Review, 74(1), 133-152.

11. Hapenciuc, C. V., Moroşan, A. A., \& Arionesei, G. (2013). Absorption of Structural Funds-International Comparisons and Correlations. Procedia Economics and Finance, 6, 259-272.

12. Kehew, R. (2000). Contractarea unui împrumut pentru a îmbunătăți piața centrală din Foç̧ani.

13. Mairate, A. (2006). The 'added value'of European Union cohesion policy. Regional Studies, 40(02), 167-177.

14. Mairate, A., \& Angelini, F. (2006). Cost-Benefit Analysis and EU cohesion policy. In Florio, M. (eds.). Cost_Benefit Analysis and Incentives in Evaluation: The Structural Funds of European Union, Edward Elgar, Cheltenham, UK, pp.49-64.

15. Miteva, A. (2005). Status and problems of development of agricultural financing in Bulgaria. Bulgarian Journal of Agricultural Science, 11(1), 79.

16. Neculita, V. (2013). The Impact of Regional Integration and European Funds on 
Economic Growth - Approaching the Countries of Central and Eastern Europe (Doctoral dissertation, "Dunarea de Jos" University of Galati).

17. Petrick, M. (2004). A microeconometric analysis of credit rationing in the Polish farm sector. European Review of Agricultural Economics, 31(1), 77-101.

18. Reti, M., \& Bak, K. (2016). The Common Agricultural Policy with and without the United Kingdom-CAP Brexit. ELTE LJ, 163.

19. Rus Ma, D., Peek-Asa, C., Baragan, E. A., Chereches, R. M., \& Mocean, F. (2015). Epidemiology of road traffic injuries treated in a large Romanian emergency department in Tirgu-Mures between 2009 and 2010. Traffic injury prevention, 16(8), 835-841.

20. Schroeder, P. W. (1996). The transformation of European politics, 1763-1848. Oxford University Press.

21. Stratan, A., Moroz, V., \& Ignat, A. (2014, January). Modernization of the agri-food sector of the Republic of Moldova in the context of international trade development. In The Research Institute for Agriculture Economy and Rural Development. International Symposium. Agrarian Economy and Rural Development: Realities and Perspectives for Romania. Proceedings (pp. 55). The Research Institute for Agriculture Economy and Rural Development. 